\title{
The identity of Marsdenia parasita (Apocynaceae, Asclepiadoideae)
}

\author{
M.J.C. Arshed ${ }^{1,2}$, E.M. Agoo ${ }^{1}$ \& M. Rodda ${ }^{3}$ \\ ${ }^{1}$ Biology Department, De La Salle University, 2401 Taft Avenue, \\ Manila 0922, Philippines \\ ${ }^{2}$ Department of Biological Sciences, Institute of Art and Sciences, \\ Far Eastern University, Nicanor Reyes Sr. Street, \\ Sampaloc, Manila 1015, Philippines \\ jeftearshed@gmail.com \\ ${ }^{3}$ Singapore Botanic Gardens, National Parks Board, \\ 1 Cluny Road, 259569 Singapore
}

\begin{abstract}
A neotype is designated for Marsdenia parasita Blanco and lectotypes are designated for its synonyms Dischidiopsis philippinensis Schltr. and Conchophyllum merrillii Schltr. ex Merr. The new combination, Dischidia parasita (Blanco) Arshed, Agoo \& Rodda is proposed. We explain why a specimen collected by Llanos and identified by him as Marsdenia parasita is not original material and thus cannot serve as a lectotype. Moreover, this gathering belongs to a different species, Dischidia vidalii Becc. Dischidia bulacanensis Kloppenb. et al. is here treated as a synonym of D. parasita.
\end{abstract}

Keywords. Dischidia, epiphyte, neotype, new combination, Philippines, typification

\section{Introduction}

Accounts of Dischidia R.Br. (Apocynaceae, Asclepiadoideae, Marsdenieae) in the Philippines began to appear in the early twentieth century, spearheaded by researchers such as Schlechter (1906, 1915), Schlechter \& Warburg (1904), Merrill (1903, 1912, 1918, 1923) and Elmer (1938). Rintz (1980) revised the genus for Peninsular Malaysia and Singapore, included some Philippine taxa as synonyms (e.g. Dischidia brachystele Schltr., D. copelandii Schltr., and D. joloensis Schltr.), and designated lectotypes (e.g. for $D$. copelandii). The latest publications of new species of Dischidia in the Philippines are those by Livshultz (2003a, 2003b, 2003c) and Ferreras et al. (2014). To date, there is no comprehensive revision of Philippine Dischidia. In addition, based on both morphological and molecular characters (Albers \& Meve, 2002; Livshultz, 2003a), Endress et al. (2018) included the genus Dischidiopsis Schltr. within Dischidia. New combinations, when necessary, will have to be made in Dischidia to accommodate the Dischidiopsis species.

In preparation for a revision of Dischidia in the Philippines, this study clarifies the identity of Marsdenia parasita Blanco. 


\section{Materials and methods}

This study is based on investigation of the herbarium material in CAHUP, DLSUH, E, K, L, LBC, PNH, P, PUH, SING and USTH. Images of additional Philippine Dischidia specimens were obtained from A, FR, MA, MO and NY herbaria. Further specimens were examined on JSTOR Global Plants (https://plants.jstor.org/, accessed on 24 Jan. 2019). Herbarium acronyms follow Index Herbariorum (Thiers, continuously updated). Specimens for which only images have been seen are marked with * and specimens not seen are noted.

\section{Taxonomic treatment}

Dischidia parasita (Blanco) Arshed, Agoo \& Rodda, comb. nov. - Marsdenia parasita Blanco, Fl. Filip. 120 (1837). - (Blanco) Merr., Sp. Blancoan.: 317 (1918), as 'parasitica'. - TYPE: Philippines, Luzon, Pasay, December 1914, (neotype US [US623774*], designated here; isoneotypes A (2 sheets), NY [NY03468643*]). (Fig. 1)

Dischidiopsis philippinensis Schltr. in Perkins, Frag. Fl. Philipp. 1: 128 (1904). TYPE: Philippines, Luzon, Occidental Mindoro, Lubang Island, April 1903, Merrill 972 (lectotype NY [NY00318581*], designated here; isolectotype K (K000910986]).

Conchophyllum merrillii Schltr. ex Merr., Fl. Manila 380 (1912). - TYPE: Philippines, Luzon, Manila, January-February 1911, Merrill 7441 (lectotype L [L0004290*], designated here).

Dischidia bulacanensis Kloppenb. et al., Hoya New 2(1): 20-25 (2014), syn. nov. - TYPE: Philippines, Bulacan Province, Angat, 100-200 m.a.s.1. Mendoza GM 31 (holotype PUH, sheet number 14618, not seen).

Notes. Merrill (1918) in his review of the Philippine plant species described by Blanco and Llanos made the new combination Dischidiopsis parasita (Blanco) Merr. based on Marsdenia parasita Blanco. He used the erroneous spelling "parasitica" that is here corrected to "parasita". Merrill considered his taxon conspecific with Conchophyllum merrillii Schltr. ex Merr. and Dischidiopsis philippinensis Schltr. and therefore Dischidiopsis parasita became the accepted name for the taxon. Merrill (1918) did not find any original material for Marsdenia parasita and based his conclusions solely on Blanco's protologue.

In the Real Jardin Botanico of Madrid herbarium (MA) we found two specimens collected by Llanos (Llanos 172) [MA757294* and MA757294-2*], the first bearing a label likely in Llanos own handwriting identifying it as (1) Dischidia nummularia, (2) Conchophyllum (Blume), and (3) Marsdenia parasita (Blanco?). The specimens have both flat leaves and pitcher-like leaves and can be identified as Dischidia vidalii Becc. 


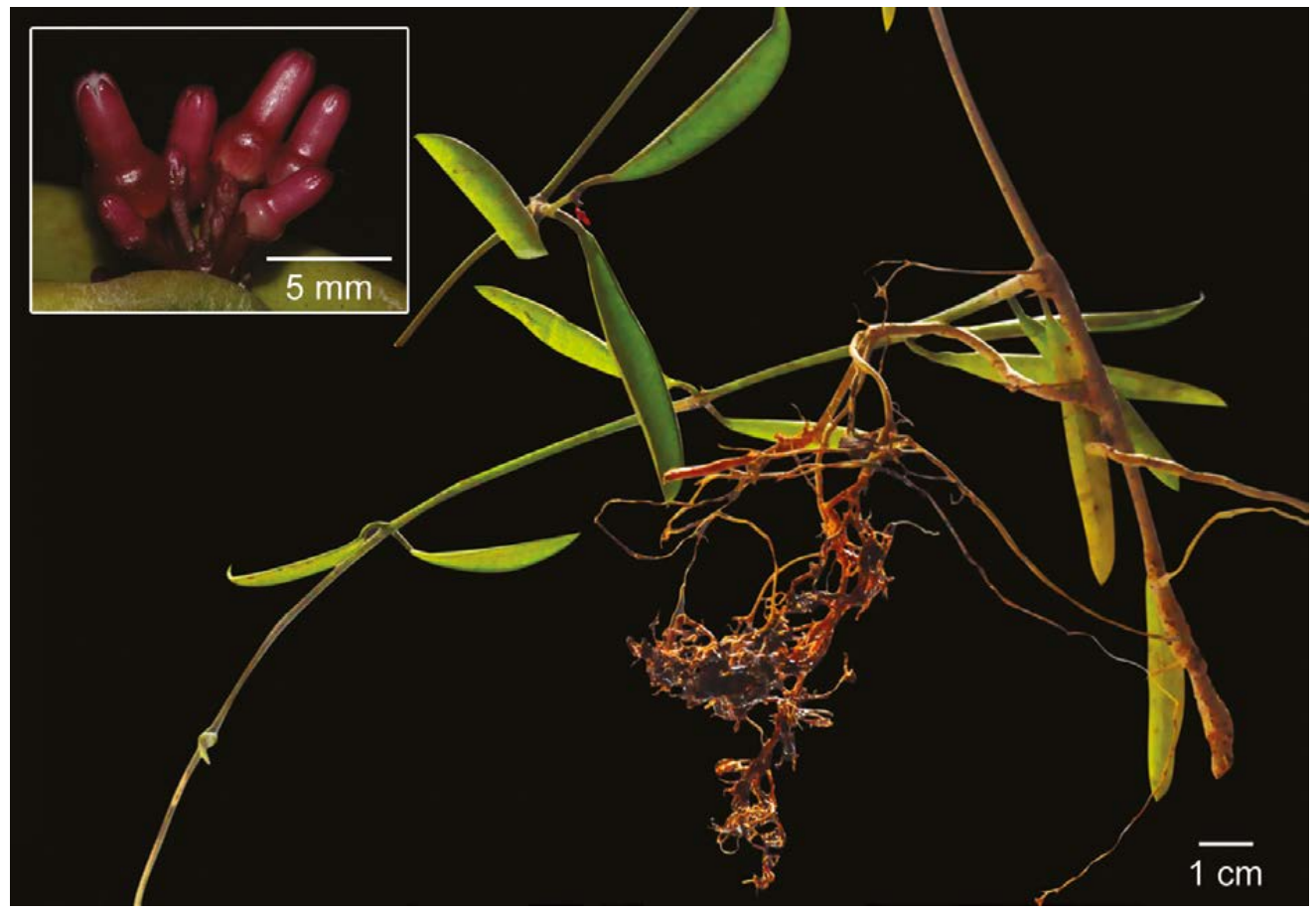

Fig. 1. Habit of Dischidia parasita (Blanco) Arshed, Agoo \& Rodda from Arshed JR-004 (DLSUH). Flowers (Inset) from Rodda MR507 (SING [SING2265537]). (Photos: M.J.C. Arshed; Inset, M. Rodda).

According to Merrill (1903), Veldkamp (1989) and Nicolson \& Arculus (2001), original material of Blanco's names of taxa described in his publication Flora de Filipinas (Blanco, 1837) are not extant. Veldkamp (1989) mentioned two periods of collection in association with Blanco and Llanos names. The first period was between 1829 and 1835 and no specimens have been traced. About 400 specimens from this period were erroneously attributed to Blanco and Llanos. They were instead collected by an unknown naval officer as explained by Vidal (Merrill, 1903; Veldkamp, 1989). During the second period (1853 to 1854), at least 270 specimens collected by Llanos and deposited in MA were traced by Quisumbing (Veldkamp, 1989), with attribution based on Llanos's hand-writing. Most were collected in Angat, Bulacan (Veldkamp, 1989). The collection Llanos 172 is part of this second period of collecting and cannot be original material for Marsdenia parasita published in 1837.

We therefore select Merrill Species Blancoanae No. 693 as a neotype of Marsdenia parasita. This is one of Merrill's "illustrative specimens" of Blanco's names that Nicolson \& Arculus (2001) suggest should be the preferred choice for neotypes in absence of original material. Among the duplicates available, US623774* is chosen as the neotype as it is the best material. Since Dischidiopsis is congeneric with Dischidia (Omlor, 1998; Albers \& Meve, 2002; Livshultz, 2003a; Endress et 
al., 2018) we here publish the new combination Dischidia parasita (Blanco) Arshed, Agoo \& Rodda.

Merrill (1923) first listed Dischidiopsis philippinensis Schltr. and Conchophyllum merrillii Schltr. ex Merr. as synonyms of Dischidia parasita without justifying his choice. Based on examination of the type specimens we agree with this synonymy based on similarities in leaf shape and texture (narrowly lanceolate and fleshy) and corolla shape (straight tube with a swollen base). This combination of characters is not observed in any other Dischidia species. Dischidiopsis philippinensis was based on Merrill 972. Schlechter in Schlechter \& Warburg (1904) did not explicitly state a holotype and no original material is present at B. We located two duplicates of Merrill 972 at NY and K. The NY sheet is fertile and bears a pencil drawing of a flower dissection and is therefore here selected as lectotype.

Conchophyllum merrillii Schltr. ex Merr. was described from material solely indicated as "On various trees, Masambong, fl. Feb.-Sept.; known only from the vicinity of Manila" with no specimen cited. Two collections by Merrill from 1911, Merrill 7441 and Merrill 1009 were deposited in L and FR, respectively. Both are annotated as "Manila and vicinity Luzon" but differ in the month of collection. Nonetheless, these specimens correspond to the description of Conchophyllum merrillii and were collected from the locality in the protologue, making these collections suitable for lectotypification. Unfortunately, both are sterile. Since Merrill 7441 [L0004290] is a richer specimen and collected earlier it is selected as lectotype.

When Dischidia bulacanensis Kloppenb. et al. was published it was compared to Dischidia philippinensis. The differences that were mentioned between the two species lie in the morphology of the tube (straight in Dischidia bulacanensis vs. bulbous in D. philippinensis) and in the shape of the sepals (round in Dischidia bulacanensis vs. linear with acute apices in D. philippinensis). Examination of the photographic illustration provided with the description of Dischidia bulacanensis shows that its flowers have a swollen base, like commonly observed in Dischidia philippinensis. The very swollen tube base observed on the drawing attached to the NY lectotype of Dischidia philippinensis [NY00318581*] is likely an artefact due to drying. The calyx lobes are variable in shape, from lanceolate to round and do not seem to be diagnostic for the separation of different taxa.

Specimens examined. PHILIPPINES: Luzon: Laguna, Bo. San Antonio, Los Baños, 2 Sep 1955, Canicosa 1708 (LBC, sheet no. LBC2957); Laguna, boundary of Los Baños \& Calamba, 9 Jul 1964, Hernag 854 (CAHUP, sheet no. CAHUP19137, CAHUP, sheet no. CAHUP19138); Laguna, cultivated in gardens, 12 Mar 1982, Soligam s.n. (CAHUP, sheet no. CAHUP28939); Rodriguez, Rizal, 3 May 2018, Arshed JR-004 (DLSUH); Cultivated in Singapore, Gardens by the Bay, 3 Nov 2013, Rodda MR507 (SING [SING2265537])).

ACKNOWLEDGEMENTS. This research is part of ongoing graduate studies by M.J.C. Arshed, which received support from DOST-SEI ASTHRDP. We would like to thank the curators of A, DLSUH, CAHUP, E, FR, K, L, LBC, MA, MO, PNH, SING, US, USTH, NY, P herbaria for allowing access and/or providing high quality images of herbarium specimens. 


\section{References}

Albers, F. \& Meve, U. (2002). Illustrated Handbook of Succulent Plants: Asclepiadaceae. Springer Science and Business Media.

Blanco, F.M. (1837). Flora de Filipinas. Manila: En la imprenta de Sto. Tomás por D. Candido Lopez.

Elmer, A.D.E. (1938). Notes on Asclepiadaceae. Leafl. Philipp. Bot. 10: 3543-3599.

Endress, M.E., Meve, U., Middleton, D.J. \& Liede-Schumann, S. (2018). Apocynaceae. In: Kadereit J. \& Bittrich V. (eds) The families and genera of vascular plants, vol. 15, Flowering Plants, Eudicots, pp. 207-411. Cham: Springer.

Ferreras, U., Kloppenberg, R.D. \& Mendoza, G. (2014). Dischidia bulacanensis. Hoya New 2 (1): $20-25$.

Livshultz, T. (2003a). Systematics of Dischidia R.Br. (Apocynaceae, Asclepiadoideae). PhD. thesis, Cornell University, New York.

Livshultz, T. (2003b). Dischidia cleistantha (Apocynaceae, Asclepiadoideae): A new Philippine endemic. Novon 13: 89-96.

Livshultz, T. (2003c). Lectotypification of Dolichostegia Schlechter (Asclepiadoideae, Apocynaceae) and a new combination, Dischidia boholensis. Taxon 52: 595-600.

Merrill, E.D. (1903). Botanical work in the Philippines. Bull. Bur. Agric. 4: 33-39.

Merrill, E.D. (1912). A Flora of Manila. Manila: Bureau of Printing.

Merrill, E.D. (1918). Species Blancoanae: a critical revision of the Philippine species of plants described by Blanco and Llanos. Manila: Bureau of Printing.

Merrill, E.D. (1923). An enumeration of Philippine flowering plants, vol. 3. Manila: Bureau of Printing.

Nicolson, D.H. \& Arculus, D. (2001). Candidates for neotypification of Blanco's names of Philippine plants: specimens in the US National Herbarium. Taxon 50: 947-954.

Omlor, R. (1998). Generische Revision der Marsdenieae (Asclepiadaceae). Berichte aus der Biologie. PhD thesis, University of Kaiserslautern. Aachen: Shaker Verlag.

Rintz, R.E. (1980). The Peninsular Malayan species of Dischidia. Blumea 26: 81-126.

Schlechter, R. (1906). New Philippine Asclepiadaceae. Philipp. J. Sci. 1: 295-301.

Schlechter, R. (1915). Asclepiadaceae Philippinenses II. Repert. Spec. Nov. Regni Veg. Beih. 13: 554-561.

Schlechter, R. \& Warburg, O. (1904). Asclepiadaceae. In: Perkins, J.R., Fragmenta florae Philippinae: contributions to the flora of the Philippine Islands, pp. 119-136. Gebrüder Borntraeger.

Thiers, B. (continuously updated). Index Herbariorum: A global directory of public herbaria and associated staff. New York Botanical Garden's Virtual Herbarium. http://sweetgum. nybg.org/science/ih/. Accessed 18 Mar. 2019.

Veldkamp, J.F. (1989). A note on Philippine collections of FM Blanco and A Llanos. Fl. Males. Bull. 10: 143-145. 
